\title{
Proposed Production Process Standardization at Function ART Indonesia to Reduce Waste of Production
}

\author{
Demara Bijak Kurniawan and Sonny Rustiadi
}

\begin{abstract}
The growth of the property business goes hand in hand with the furnishing industry in Indonesia. The construction of apartments, minimalist houses which adjust to the limitations of land in Indonesia creates changes in furnishing designs which are minimalist, simple, and multifunctional that support, such as space saving models. In Indonesia, many space saving products are introduced by foreign companies such as IKEA and Informa. Function.id is one of the small businesses that has a goal to fulfill the needs of space saving product in Indonesia. With some limitations, Function.id does the production process using the makloon / outsource method. However, because the concepts applied are not standardized and well-structured, instead it creates a problem in the production process. Therefore, the purpose of this research is to identify the problem and to standardize the makloon production process of Function.id to be implemented in Function ART Indonesia.

The approach of this research is qualitative with expert interview, then continued to define the production process and communication process of Function.id and its vendor to ease the analysis of this research. After that do a root cause analysis to map the problems of Function.id with ishikawa diagram as a framework. The main causes of problems faced by Function.id are no designer specialist, limited source of vendor, lack of supplier source, having no a precise and measurable product design for vendor, having no clear letter of agreement, unstructured communication process, unstable ordering pattern, and having no standardization guidelines.

Solutions and improvements that can be applied to develop Function.id into Function ART Indonesia in its production process are creation of a structured and create an SOP for production process with instruments of communication to vendor and supplier with implementation of heijunka. Also, some requirements that needs to be prepared before the production process could be implemented, such as do a collaboration with designer, design maximizing, letter of agreement and survey for supplier and vendor.
\end{abstract} SOP.

Index Terms-Production Process, Root Cause Analysis,

\section{INTRODUCTION AND RESEARCH OBJECTIVES}

Property business growth goes hand in hand with furnishing industry. The construction of apartments, minimalist houses that accustom to the limitations of existing land, makes the need of furnishing with simple, minimalist, multifunctional and space saving design also increase. Real Estate industry contribute $2.84 \%$ of National gross domestic product in 2019 which increased by 0.39 point compared to the previous year, indeed the real estate or property industry experienced a significant decline since 2016.

Published on August 5, 2020.

Demara Bijak Kurniawan, Institut Teknologi Bandung, Indonesia. (demara_bijak@sbm-itb.ac.id)

Sonny Rustiadi, Institut Teknologi Bandung, Indonesia.

DOI: http://dx.doi.org/10.24018/ejbmr.2020.5.4.446
But expert believe that in 2020 Property sector has the potential to be even brighter. This prediction occurs because of the new Bank Indonesia policy towards interest rate cuts Reverse Repo Rate (BI7DRRR) to $5.25 \%$ or decreased by 25 basis points (bps) supported by relaxation of Loan to Value (LTV) and Finance to Value (FTV) to finance property ownership, both landed houses and residential houses and office houses and Shop Houses [1]. The relaxation of this LTV will affect not only first home buyers, but also investment buyers because it can easily and quickly buy second, third, and so on properties to be used as investment portfolios.

\section{A. $\quad$ Statement of the Problem}

The furnishing industry can be said to have quite fierce competition, starting a business with an in-house production process also requires quite a high amount of capital investment for equipment and machines to expand products in order to get bigger market. Therefore, the production process using outsourced methods or makloon is chosen by Function.id to overcome high capital investment. But running a production process with an outsourced method is not that simple, various obstacles were discovered by Function.id in the process of running it.

Function.id can be started just with network (vendor), human resources (internal), and the idea itself, but did not last for long, because of some problems in the production process that uses outsource method, one of which is the cost that must be incurred in the process of research and development, transport, and the cost of production with a made to order model, which is due to an immature and unstandardized production process. Besides that, the communication process with the vendor is also not going well, which is also one of the reasons why the production process using outsource method cannot be run well by Function.id. In order to deepen the business issue of Function.id a root cause analysis is used. The results of the analysis are expected to help find solutions to the Function.id production process problem to formulate and implement it into the development of Function.id namely Function ART Indonesia

\section{B. Research Objectives}

This study aims to see the problems that Function.id experienced in its production process with outsource method, then to formulate the proper standardize production process strategy to be implemented at Function ART Indonesia, and also to find the proper way of implementing the production process strategy for Function ART Indonesia. The result of this research is expected to provide solutions in solving the problems of Function.id to then be implemented at Function ART Indonesia so that the problems experienced by Function.id are no longer a hindrance for Function ART Vol 5 | Issue 4 | August 2020 
Indonesia, especially in its production process.

\section{RESEARCH MethodOLOGY}

Qualitative research is developing an understanding of the concepts and theories held by the people being studied [2]. In this research, author will engage qualitative research, therefore author will use interview for the insight of the situation on the ground according to some experts from three different background and root cause analysis for internal insights of the research object itself. There are two types of source of data collection, primary and secondary. Primary data is a data that researcher has collected by themselves and secondary data is a data that has been collected and utilized by researcher by observing a research that was published by someone else to achieve research objective.

\section{BUSINESS ISSUE EXPLORATION}

\section{A. Production Process Analysis}

Broadly speaking, the type of production process has two main components, which is volume and variety of product. There are five types of process, which are projects, jobbing, batch, mass and continuous. The process that Function.id use is batch process with medium variety and volume of product.

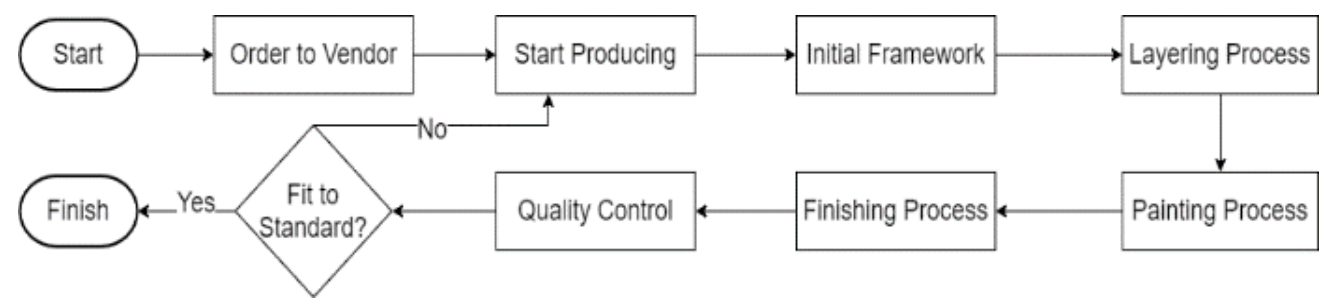

Fig. 1: Function.id Production Process

Function.id production process as seen above did not have a good quality control and was also hard for Function.id to keep control of the product that still in the process. Vendors often had difficulty in the process of producing Function.id products because it was basically not their expertise in making crafting products that must be worked out in detail. And Function.id did not have the clear picture as their guidelines to make the products, so that sometimes the quality that Function.id vendor produce did not meet Function.id standard.

The problem of the production process experienced by Function.id was not only lack of standardization of the process, but also because of the unstructured communication patterns between Function.id and its vendors. The communication patterns carried out by Function.id did not have a good structure, everything was limited to ordering between consumers and producers. Although there is an important point that is forgotten by Function.id, which is that vendors are an important component in Function.id production process, which should be treated specifically and professionally.

\section{B. Communication Process Analysis}

As mentioned above one of the problems in Function.id was its missing link of communication process with vendor between Order to vendor and Finished Product flow which made the finished product sometimes not in accordance with Function.id standard. Communication can be defined as the process of sending information and understanding each other [3]. Commonly there are 8 main elements in communication process in order to deliver an information.

Lack of resources in Function.id is what inspire it to find a way to maximized and make efficient use of vendor. But there are some miss communications between Function.id and its vendor which is one of the main factors of Function.id production process problem. Communication is the transmission of information and meaning from one individual or group to another [4]. The problems are that the transmission of message and meaning from Function.id to its vendor is not done efficiently which cause various miss perceptions from each party.

TABLE 1: Communication Instrument of Function.id

\begin{tabular}{|c|c|c|}
\hline PROCESS & $\begin{array}{l}\text { SENDER (S) - } \\
\text { RECEIVER (R) }\end{array}$ & INSTRUMENT \\
\hline Message & $\mathrm{S} \rightarrow \mathrm{R}$ & Sample Product \\
\hline Encoding & $\mathrm{S} \rightarrow \mathrm{R}$ & Product Design \\
\hline Channel & $\mathrm{S} \leftrightarrow \mathrm{R}$ & $\begin{array}{c}\text { Verbally } \\
\text { Writing/Picture } \\
\text { Phone }\end{array}$ \\
\hline Decode & $\mathrm{S} \leftarrow \mathrm{R}$ & Verbally \\
\hline Feedback & $\mathrm{S} \leftrightarrow \mathrm{R}$ & $\begin{array}{l}\text { Verbally } \\
\text { Phone }\end{array}$ \\
\hline
\end{tabular}

As in Table 1 above, can be seen that the instrument in Function.id communication flow towards the vendor is very simple, from encoding to feedback received. Basically, communication is limited to verbally without the support of instruments that can direct the intent and purpose of verbal communication, so that each party tends to have a different picture between the messages delivered and received. For example, the message that wants to be delivered by Function.id is to make a product sample with encoding done by Function.id using a product design like in Fig. 2 below. Because the product design carried by Function.id is not detailed so that during the discussion process many questions arise from the vendor and the explanation from Function.id itself is only in accordance with its visualization without any clear specification details, which results in mismatch between the message that is being conveyed and accepted by each party. 


\section{Root Cause Analysis}

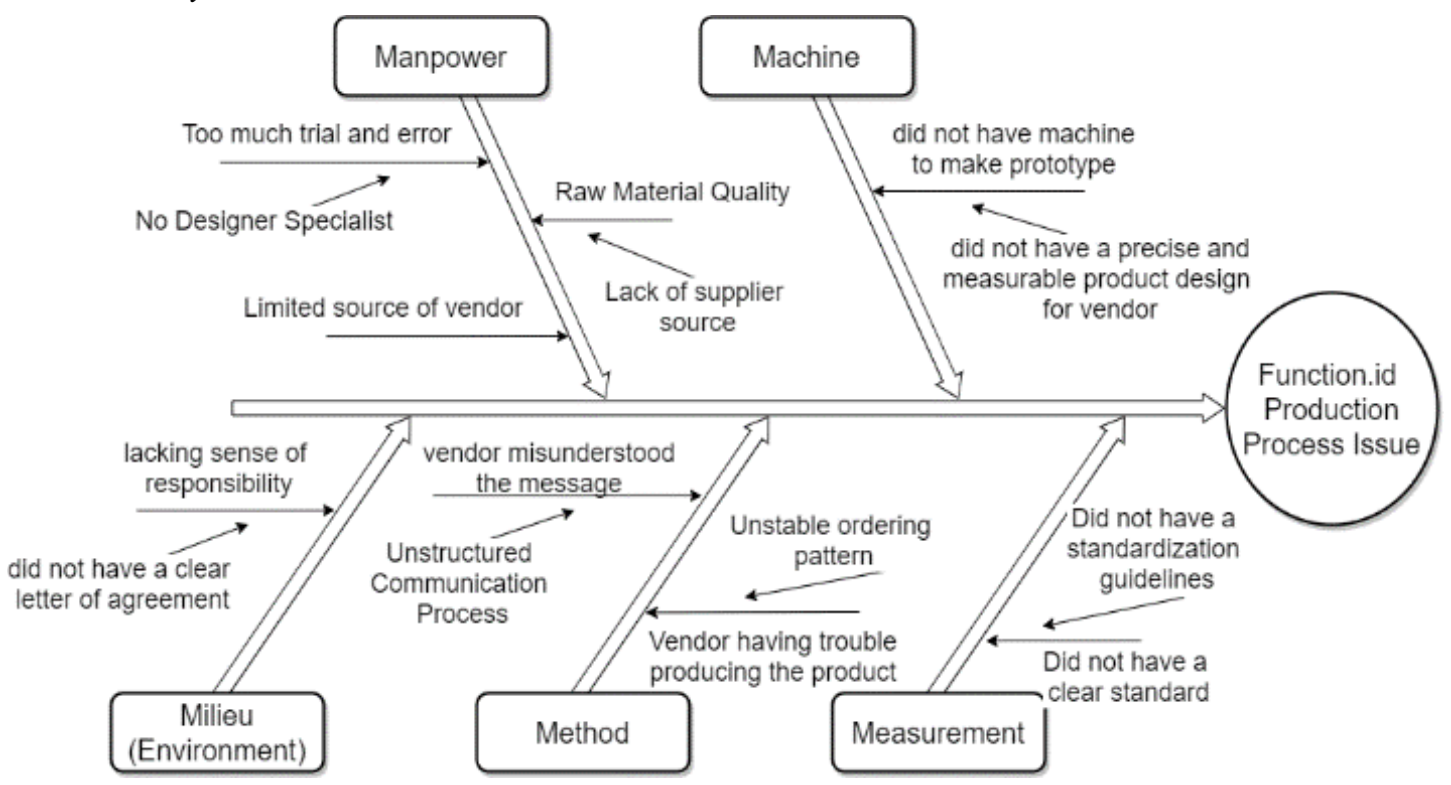

Fig. 2: Function.id Root Cause Analysis

\section{Manpower}

Function.id found two issues about manpower, which is no specialist in design and limited source of vendor. As a company that depends on vendor to produce the product, this two issues are vital, the absence of a designer in Function.id has made it hard to give a clear picture of what Function.id wants to build to vendor, that makes the product, which vendor produces sometimes, does not fit to Function.id standard and makes Function.id spend too much cost in trial and error or research and development.

Also, the limited source of vendor which sometimes makes Function.id gets no leverage and options when it comes to get the lowest price out of the vendor, and when their production capacity is full, Function.id must delay the production schedules that make consumers wait longer than usual.

For the material issue, every material for production that Function.id has used is fully prepared by the vendor, sometimes Function.id uses the remaining material that already has used by the vendor to make Function.id product especially for decoration product. Thus Function.id cannot choose the quality of the material, and also sometimes the price of the raw material is unstable from the vendor if Function.id uses new material, because one fresh material can be used to make a table but instead of being used as a material for Function.id product, which the rest of the material cannot be used to make a table again, consequently the vendor will waste a piece of fresh material if Function.id orders less than the size of the material, this happens also because Functin.id does not have a supplier source.

\section{Machine}

In terms of machine, Function.id does not have an adequate machine to at least produce a prototype as an instrument to show to vendor about how Function.id wants the product to be. That is why Function.id only tries to explain to vendor about the product by design template which has not been done in detail. As one of the experts explain the process of finding the right vendor for their product is by showing them a prototype. Providing prototypes to potential vendors can make it easier for them to adjust to their own capacity, determine prices, and production times. So that the communication process can be easier.

This also makes too much trial and error in the process of producing products from Function.id, also related to the quality produced. Function.id never conducts trials on designated vendors to make one product sample, just by showing a design drawing. So that the trial and error are carried out on products which are ordered by consumers. Sometimes production results did not reach the minimum standard that Function.id had. But the processing time is long adrift, so function.id must immediately enter the process of shipping goods to consumers with low quality product.

\section{Milieu (Environment)}

Function.id does not have a fix working hour that makes lack of attention to work discipline inside this business. Because basically in Function.id there is no clarity in writing related to the job desk of each individual, how to work, the distribution of rights and obligations, also planning related to the development of Function.id. Basically Function.id does not have a letter of agreement in building this business. Because the lack of clarity in writing makes the working atmosphere in Function.id does not seem effective.

Irregular working hours, unmeasured work targets, etc. are caused by the absence of binding evidence between each individual to develop this business, which makes sense of belonging to Function.id less well formed in every individual involved in it. Because a poor work culture also creates various negative perceptions between one another that makes Function.id less solid from its own internal perspective. Therefore, the work environment in Function.id becomes less effective and orderly.

\section{Measurement}

As mentioned above Function.id did not have a clear standard, be it just a standard operational procedure, product quality, vendor standardization, communication with vendor, 
even the production process did not have a clear pictures and clear instrument. And it is hard to measure the productivity of the company without clear standard. Standards that are not agreed upon properly by each individual make Function.id difficult to make good decisions, so that dependency between individuals is very high. If from Function.id cannot make the right decision, the effect on related parties such as vendors will also be bad.

Standardization is important for a business. in Function.id, it affects all parts from upstream to downstream, if the internal company itself does not have good standardization, then the vendor will be difficult to understand the message to be conveyed by Function.id so that the standards they create in the process of making Function.id products only adjust to the standards they have, which basically have not yet reached the standards intended by Function.id itself, both related to the level of detail, quality, up to the time of work.

\section{Method}

In this term the focus is about communication process with vendor. Function.id production process mostly relies on vendor to produce its product. When it is doing so, communication between each party is vital. Each party must make sure about the delivery of message from sender has been done perfectly, the receiver understands what senders want and receiver gives feedback to sender. And Function.id does not have a good instrument to do so, just relies on verbal communication and an unclear product design.

Then related to the unstable Function.id ordering pattern, which results in burdening the production flow of the vendor itself, with irregular patterns and using raw material owned by the vendor sometimes make some raw material owned by the vendor waste, because it cannot be calculated clearly of how many orders will be made in a week. Though vendors also still have other orders that they must complete before the term of the agreement with their customers expires. Sometimes Function.id product is done after they complete orders from consumers, because Function.id only orders a small quantity, which benefit for the vendor is not much but the production requires quite a long time.

\section{Business SOLUTION}

\section{A. Proposed Solution}

After root cause is elaborated, the solution towards Function.id production issue will be developed according to Function.id needs and issues in order to improve the production process issue. In the improve step, they turn to creative thinking about the specific changes that can be made in the process and other things that can be done to have the desired impact on process performance [5].
TABLE 2: Root causes and proposed solutions

\begin{tabular}{|c|c|c|}
\hline NO & ROOT CAUSE & PROPOSED SOLUTIONS \\
\hline 1 & Limited source of vendor & $\begin{array}{c}\text { Vendor survey } \\
\text { (Based on expert interview) }\end{array}$ \\
\hline 2 & No designer specialist & $\begin{array}{c}\text { Do a collaboration with designer } \\
\text { (Based on expert interview) }\end{array}$ \\
\hline 3 & Lack of supplier source & $\begin{array}{c}\text { Supplier survey } \\
\text { (Based on expert interview) }\end{array}$ \\
\hline 4 & $\begin{array}{l}\text { Did not have a precise and } \\
\text { measurable product } \\
\text { design for vendor }\end{array}$ & $\begin{array}{c}\text { Maximizing in design } \\
\text { (Based on expert interview) }\end{array}$ \\
\hline 5 & $\begin{array}{l}\text { Did not have a clear letter } \\
\text { of agreement }\end{array}$ & $\begin{array}{l}\text { Make a letter of agreement } \\
\text { (Based on expert interview) }\end{array}$ \\
\hline 6 & $\begin{array}{l}\text { Did not have a } \\
\text { standardization guideline }\end{array}$ & Create an SOP for each process [8] \\
\hline 7 & $\begin{array}{l}\text { Unstructured } \\
\text { communication process }\end{array}$ & $\begin{array}{c}\text { Make a structured communication } \\
\text { flow [4] }\end{array}$ \\
\hline 8 & Unstable Ordering pattern & $\begin{array}{l}\text { Implement Heijunka } \\
\text { (Ohno, T. 1988) }\end{array}$ \\
\hline
\end{tabular}

1. Limited source of vendor

Limited source of vendors and the absence of designer specialists that cause too much trial and error for Function.id. Conducting a survey to increase vendor access is something that must be done by Function.id, it also needs to be recorded properly to facilitate the selection of vendors in accordance with needs by Function.id itself. Based on interviews conducted with experts, in searching for vendors, requires qualifications from the company itself by making a list of vendor criteria as to what companies are looking for to make the desired product. For example, a list can be made of what machines are owned by the vendor that the company is surveying and how their work is done or directly try to make sample items for the product that company wants to make.

TABLE 3: Vendor Qualification

\begin{tabular}{|c|c|c|c|}
\hline \multirow{2}{*}{ SUBJECT } & \multicolumn{3}{|c|}{ QUALIFICATION } \\
\hline & WOOD & PLASTIC & ELECTRICAL \\
\hline \multicolumn{4}{|l|}{ Management } \\
\hline Legal Status & $\mathrm{Y}$ & $\mathrm{N}$ & $\mathrm{N}$ \\
\hline Employee & $>6$ & $>4$ & $>2$ \\
\hline $\begin{array}{l}\text { Minimum } \\
\text { Experience }\end{array}$ & $>2$ Years & $>2$ Years & $>2$ Years \\
\hline \multicolumn{4}{|l|}{ Infrastructure } \\
\hline Finishing Room & $\mathrm{Y}$ & $\mathrm{N}$ & $\mathrm{N}$ \\
\hline Inventory Room & $\mathrm{Y}$ & $\mathrm{N}$ & $\mathrm{N}$ \\
\hline \multicolumn{4}{|l|}{ Bench Tools } \\
\hline Bench Drill press & $\mathrm{Y}$ & $\mathrm{N}$ & $\mathrm{N}$ \\
\hline Air Compressor & $\mathrm{Y}$ & $\mathrm{N}$ & $\mathrm{N}$ \\
\hline Bandsaw/Table Saw & $\mathrm{Y}$ & $\mathrm{N}$ & $\mathrm{N}$ \\
\hline CNC Laser Cut & $\mathrm{N}$ & $\mathrm{Y}$ & $\mathrm{N}$ \\
\hline $\begin{array}{l}\text { Bench Power } \\
\text { Supply }\end{array}$ & $\mathrm{N}$ & $\mathrm{N}$ & $\mathrm{Y}$ \\
\hline \multicolumn{4}{|l|}{ Power Tools } \\
\hline Sander & $\mathrm{Y}$ & $\mathrm{N}$ & $\mathrm{N}$ \\
\hline Nail Gun & $\mathrm{Y}$ & $\mathrm{N}$ & $\mathrm{N}$ \\
\hline Hand Drill & $\mathrm{Y}$ & $\mathrm{N}$ & $\mathrm{N}$ \\
\hline Heat Gun & $\mathrm{N}$ & $\mathrm{Y}$ & $\mathrm{N}$ \\
\hline Air Solder & $\mathrm{N}$ & $\mathrm{N}$ & $\mathrm{Y}$ \\
\hline Digital multimeter & $\mathrm{N}$ & $\mathrm{N}$ & $\mathrm{Y}$ \\
\hline
\end{tabular}

\section{No Designer Specialist}

For the absence of designer specialist that causes too much trial and error for Function.id could also use the same method as looking for new source of vendor by creating designer criteria such as what is needed, related to the work agreement can be with direct hire as permanent employee, part-time 
designer, project based, buy designs, royalty system for each product made, in accordance with a mutual agreement from Function.id and the designer. Just like the one of the experts says, doing a collaboration with designer especially designer, which is still in its early stages, has several benefits, besides lower costs. It is also easy to find in accordance with the needs of the Function ART Indonesia itself, as one of the instrument for communication of FAI to its vendor. Based on the needs of FAI, the designer qualification and example of designer list can be seen in the table below.

TABLE 4: Designer Qualification

\begin{tabular}{|l|c|c|}
\hline \multirow{2}{*}{\multicolumn{1}{|c|}{ SUBJECT }} & \multicolumn{2}{c|}{ QUALIFICATION } \\
\cline { 2 - 3 } & $\begin{array}{c}\text { PRODUCT } \\
\text { DESIGNER }\end{array}$ & $\begin{array}{c}\text { ENGINEERING } \\
\text { DESIGNER }\end{array}$ \\
\hline Minimum Experience & $>1$ Year & $>1$ Year \\
\hline Portfolio & $\mathrm{Y}$ & $\mathrm{Y}$ \\
\hline Skills & & $\mathrm{N}$ \\
\hline Freehand Drawing & $\mathrm{Y}$ & $\mathrm{Y}$ \\
\hline Coreldraw & $\mathrm{Y}$ & $\mathrm{N}$ \\
\hline Adobe Photoshop & $\mathrm{Y}$ & $\mathrm{N}$ \\
\hline Google sketchup & $\mathrm{Y}$ & $\mathrm{Y}$ \\
\hline Autocad & $\mathrm{Y}$ & $\mathrm{Y}$ \\
\hline Instrumentation & $\mathrm{N}$ & $\mathrm{Y}$ \\
\hline Arduino & $\mathrm{N}$ & $\mathrm{Y}$ \\
\hline Autodesk Eagle / Altium & $\mathrm{N}$ & $\mathrm{Y}$ \\
\hline $\begin{array}{l}\text { Proteus ISIS / Ni } \\
\text { Multisim }\end{array}$ & $\mathrm{N}$ & \\
\hline
\end{tabular}

\section{Lack of Supplier Source}

Lack of supplier source, having a trusted supplier can help Function.id to determine the raw material that will be used with Function.id own standards. With good raw material can also make it easier for vendors to process the material. For example, if the material that vendor has is low quality, it is possible that the vendor must provide an extra touch to make the material suitable for use and will definitely take time and will reduce the quality of the product itself.

However, because Function.id does not have its own suppliers and most of them use the remaining production materials from vendors for Function.id decoration products, the quality of raw materials cannot be chosen by themselves. Therefore, Function.id must conduct supplier surveys with self-determined qualifications and must also be properly recorded.

TABLE 5: Supplier Qualification

\begin{tabular}{|l|c|c|c|}
\hline \multirow{2}{*}{ SUBJECT } & \multicolumn{3}{|c|}{ QUALIFICATION } \\
\cline { 2 - 4 } & WOOD & PLASTIC & ELECTRICAL \\
\hline Legal Status & $\mathrm{Y}$ & $\mathrm{Y}$ & $\mathrm{N}$ \\
\hline Offline Store & $\mathrm{Y}$ & $\mathrm{Y}$ & $\mathrm{N}$ \\
\hline Online Payment & $\mathrm{Y}$ & $\mathrm{Y}$ & $\mathrm{Y}$ \\
\hline Packaging Service & $\mathrm{Y}$ & $\mathrm{Y}$ & $\mathrm{Y}$ \\
\hline $\begin{array}{l}\text { Size Customization } \\
\text { Service }\end{array}$ & $\mathrm{Y}$ & $\mathrm{Y}$ & $\mathrm{N}$ \\
\hline Product Catalogue & $\mathrm{Y}$ & $\mathrm{Y}$ & $\mathrm{Y}$ \\
\hline Product Warranty & $\mathrm{Y}$ & $\mathrm{Y}$ & $\mathrm{Y}$ \\
\hline
\end{tabular}

4. Did not have a precise and measurable product design for vendor

Having no precise and measurable product design for vendor. As mentioned by several experts in the expert interview in previous chapter, it is said that providing prototypes or detail product design and specification is one of communication instrument for vendors, to make it easier for companies to deliver their messages and make it easier for vendors to understand the purpose of the messages delivered by the company. In case of Function.id, because Function.id does not have a machine to make prototypes, there are other options that can be done, namely by maximizing the design that will be shown to the vendor.

\section{Did not have a clear letter of agreement}

Having no clear letter of agreement. In Function.id there is no agreements made in writing between each owner, all agreements are only agreed verbally, as well as the job desk of each party. it can be said that in starting a brand, Function.id did not look through a careful preparation, which makes each owner does not know their rights and obligations as a whole and what the limits of each task. And affects the lack of responsibility of each owner, so the execution is less able to run properly.

A contract is an agreement under which two parties make reciprocal commitments in terms of their behavior to coordinate [6]. An agreement between owners could be a guideline, to clarify the nature of the business, job desk of each parties, rights and obligations, and even how to settle a conflict. Also an expert says that having a clear contract or letter of agreement between each individual in a business.

\section{Did not have a standardization guideline}

Did not have a clear standard, Function.id does not have benchmarks related to what must be done in each process, in the absence of appropriate benchmarks or standards from Function.id itself it will be difficult to determine the things that must be done step by step and determine whether the resulting output is appropriate by its standards. Therefore, Function.id must make a Standard Operation Procedure that is measurable and structured in every production process from beginning to end for Function ART Indonesia. Standard operating procedure is needed to make sure that the production process of Function ART Indonesia could work and last. Standard Operating Procedures (SOPs) are a series of written instructions documenting routine or repetitive activities that are followed by employees in an organization [7].

Standard Operational Procedure (SOP) is the sequence of steps (or job implementations), where the work is done, relates to what is done, how to do it, when to do it, where to do it, and who does it [8]. The application of SOP must be in line with any process that is passed by Function.id so that in its implementation from input to output gets the appropriate results. SOP for Function ART Indonesia can be made in the form of a production process that is tailored to their needs, structured and has guidelines regarding what to do with the supporting instruments as well.

\section{Unstructured communication process}

Unstructured Communication Flow, Function.id communication process as mentioned in previous chapter is lacking in its instrument to get a better understanding between sender and receiver. Communication process is a complex thing, there are barriers in each process. In order to improve a communication process for Function ART Indonesia, Function.id has to overcome these barriers. The barriers can 
be divided into three parts such as, physical barriers, semantic barriers and psychosocial barriers. Physical barriers is any number of physical distractions that could interfere with the effectiveness of communication such as, drop-in visitors, telephone call, distances between people, static on the radio, and walls [9].

Semantic barrier is when communicating with other person, no matter what kind of communication means is utilized, it is vital to make use of appropriate words, vocabulary and language [10]. Using the proper language to get a better understanding between each party is important, just like Function.id experienced, because Function.id does not have the proper tools, sometimes it is hard to explain the product Function.id wants to make to vendor with only verbal communication. The last is psychosocial barrier, psychosocial barrier often involves a psychological distance between people that is similar to actual physical distance [9]. In order to minimize the disruption in process of delivering a message for FAI, company must have an instrument for each message that wanted to be delivered.

The instrument of communication can be adjusted to Function ART Indonesia needs, from the communication patterns that have been run by Function.id so far without any instruments to convey the message, making communication with vendors is very inefficient so far. To overcome barriers that can emerge, clear instruments can be used as a form of encoding of Function ART Indonesia such as forms to place orders according to order specifications, detailed designs, up to quality control checklists to facilitate assessment of the quality of Function ART Indonesia as well as to facilitate Function ART Indonesia to discuss the shortcomings of its products with vendors. All instruments can be adjusted according to what message wanted to be delivered to the vendor.

\section{Unstable ordering pattern}

Unstable ordering pattern, as mentioned in the previous chapter, the instability of ordering patterns to vendors raises several problems, also making Function.id difficult to make an offer of the best price vendor can give. With the instability of Function.id ordering pattern also makes a lot of wasted costs that are not needed if the order pattern can be made stable. In this case, Function.id can use Heijunka which is a tool for lean manufacturing as a guideline for better ordering patterns that is also useful for minimizing the waste of resources owned by Function.id itself.

\section{B. Proper Standardize Production Process Strategy to be Implemented in FAI}

In order to make a proper standardize production process strategy, researcher meant to improve what has been done by Function.id on the previous chapter. Based on proposed solution of root cause analysis above using lean manufacturing to make a leaner and effective production process for Function ART Indonesia and make a standard operation procedure to make sure that Function ART Indonesia production process could run properly for a long time.

Based on the analysis in the previous chapter, Function.id production process issue can be seen on figure 2 using root cause analysis with five main subjects which are manpower, machine, milieu, measurement, and method. Then an analysis is conducted on what can be done to overcome these problems by creating a new production process that is more detailed, structured, and clear, supported by supporting instruments to carry out every process that will be passed by Function ART Indonesia, Mr Dani Hadiyantara as one of the expert said in the interview that "Production process is very important for a business, whatever its business, if it does not have a clear and structured production process, the possibility of its survival is unpredictable".

In the development of the production process from Function.id to Function ART Indonesia (FAI) requires a considerable development, also by applying the concept of lean manufacturing to minimize seven wastes. Most problems of Function.id production process arise from unstructured communication flow with vendors and unstable ordering patterns that burden vendors. Changes for the production process can be started from the order flow, process quality control, to assembly. If previously Function.id only relied on one vendor from the beginning to the end, in FAI the use of vendors only focuses on the assembly process only, raw material must be provided by FAI to maintain the quality of raw material. So, FAI must have its own supplier to provide raw material, just like Fady as one of the expert said in the interview that "raw material is an important factor for our company, the better the quality of the raw material, the easier it is for companies to process it into good quality finished product". FAI must be able to ensure that each process produces output as desired, both from confirming the availability of vendors and suppliers to delivery of raw materials from suppliers to vendors. Also prepare the worst possible possibilities that can arise from each process, such as vendors are not ready or the material is not available.

Then the production process adjusted for products from FAI itself, each product has another function, such as providing lighting functions to beautify its products, other vendors in their fields are needed, in this case electrical. Each process from each vendor must be properly aligned. So that at the time of its application there will no longer be a waste of unnecessary transportation costs from one vendor to another until the assembly is carried out by the FAI itself. In this case, the production process for FAI can be divided into two stages, namely the pre-production stage and production stage. Each of which is related to one another just as Fig. 3 and 4 .

At the pre-production stage, the stage is divided into 2 more stages, namely stages A and B. Where stage A is the initial stage of finding vendors and suppliers. At this stage, each vendor and supplier are bound to each other in which the stage cannot be continued before FAI can find a vendor who is ready for production and a supplier who has the appropriate raw material specifications and is ready to use or does not exceed the 2-day deadline to prepare the raw material. Because raw material must be received by the vendor within this time period, with the aim that it does not interfere with the production process of the vendor itself, then proceed to the next stage of the production stage. 


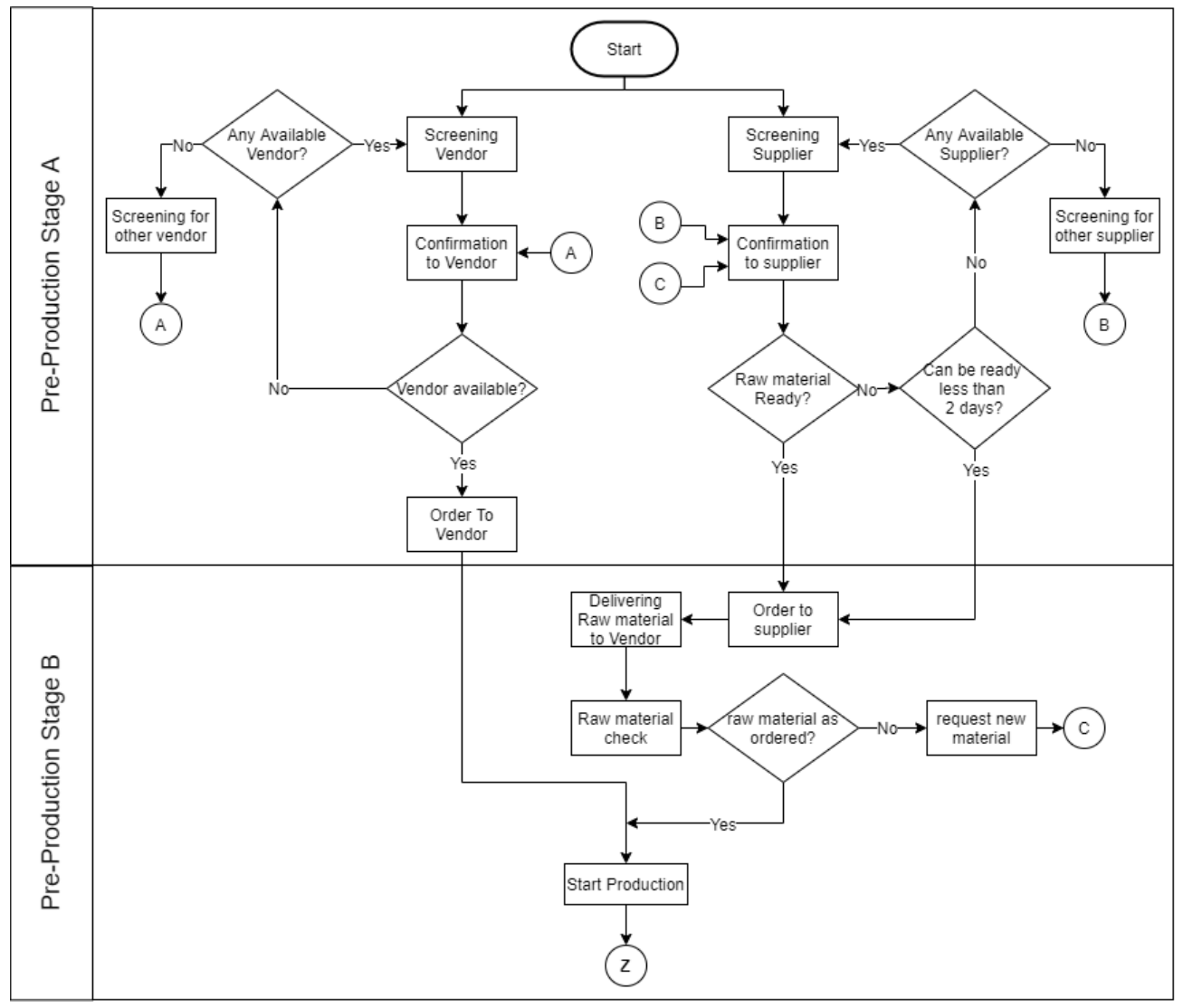

Fig. 3: FAI Pre-Production Stage

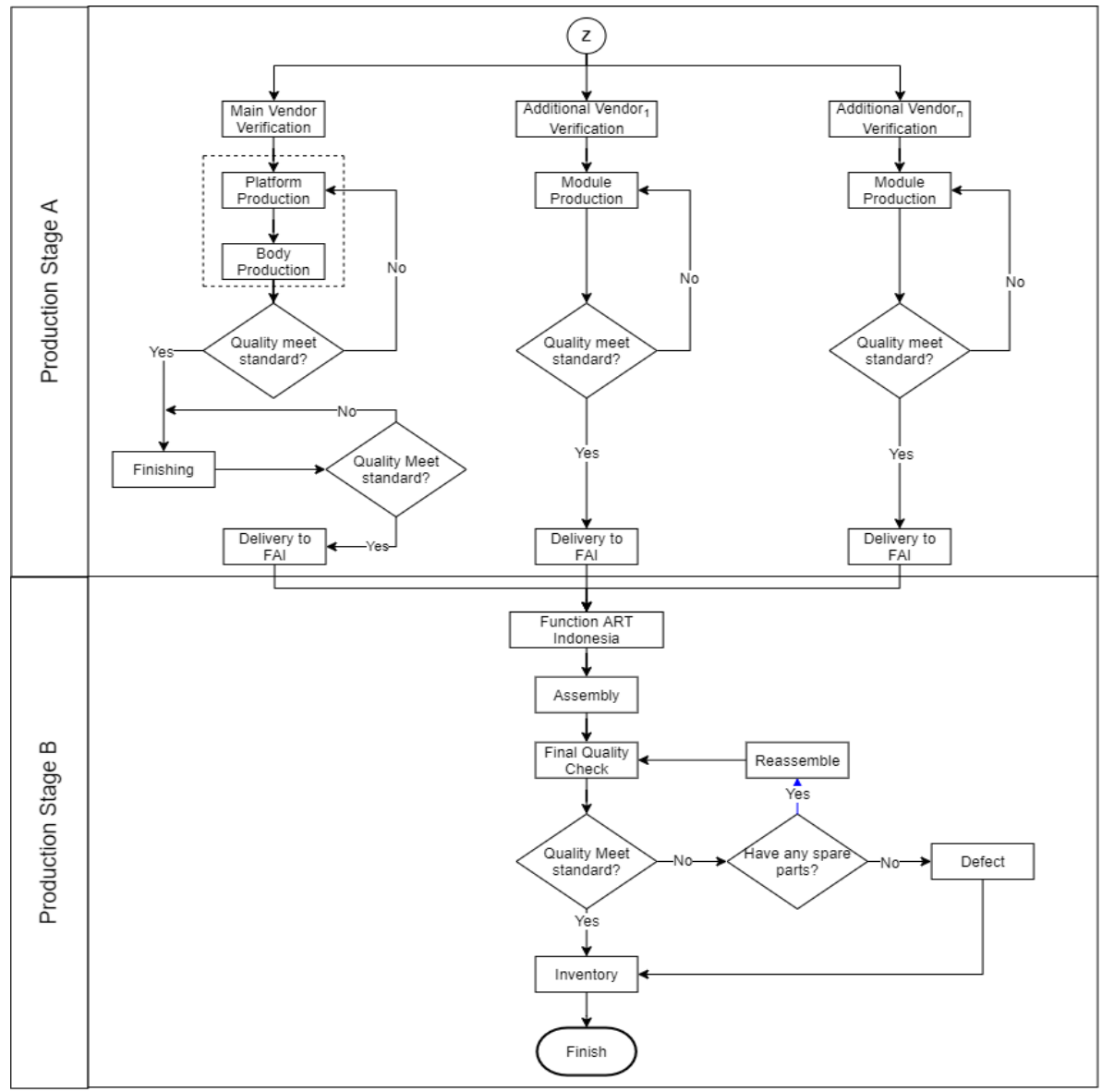

Fig. 4: FAI Production Stage 
At the production stage, just like the pre-production stage, it is also divided into two parts, parts A and B. where part A is the production stage which is carries out outside Function ART Indonesia, namely the vendor. Vendors produce modules in accordance with FAI orders, the aim of which is to maintain the confidentiality of FAI products, as well as to shorten production time, so that one batch of products can be carried out in parallel, not sequentially. After that, the modules produced by the vendor are sent to FAI to enter stage B, namely assembly and inventory recording, the reason the assembly process is carried out by FAI is to maintain the quality of the product itself, to ensure that every finished product can be sold immediately and used by consumers.

All processes above have been adjusted to the results of the analysis carried out previously, with the aim to be detailed, structured, and clear. Instruments are used to simplify the communication process with related parties, in this case vendors and suppliers, FAI can use a document to shown to the related parties so that it is more transparent and the delivery of messages can be easier, as Mrs Yuliana said in the expert interview that "In communication with the vendor, company must have a good communication mechanism with adjusted instruments based on its need". The instruments used are:

TABLE 6: FAI Communication Instrument

\begin{tabular}{|c|c|c|}
\hline Process & $\begin{array}{c}\text { Related } \\
\text { parties }\end{array}$ & Instrument \\
\hline $\begin{array}{l}\text { Screening Vendor } \\
\text { and Supplier }\end{array}$ & FAI & $\begin{array}{l}\text { - Vendor List } \\
\text { - Supplier List }\end{array}$ \\
\hline $\begin{array}{l}\text { Confirmation to } \\
\text { Vendor }\end{array}$ & Vendor & $\begin{array}{l}\text { - Product Design } \\
\text { - Request for Quotation }\end{array}$ \\
\hline $\begin{array}{l}\text { Confirmation to } \\
\text { Supplier }\end{array}$ & Supplier & - Request for Quotation \\
\hline Order to Vendor & Vendor & $\begin{array}{l}\text { - Purchase Order } \\
\text { - Payment Receipt (Down } \\
\text { Payment) }\end{array}$ \\
\hline Order to Supplier & Supplier & $\begin{array}{l}\text { - Purchase Order } \\
\text { - Payment Receipt (Down } \\
\text { Payment) }\end{array}$ \\
\hline Raw Material Check & Supplier & - Goods Received Checklist \\
\hline $\begin{array}{l}\text { Raw Material } \\
\text { Confirmed }\end{array}$ & Supplier & - Payment Receipt (In Full) \\
\hline Vendor Verification & Vendor & - Order Fulfillment Checklist \\
\hline Quality Control & Vendor & - Quality Control Checklist \\
\hline Delivery to FAI & Vendor & $\begin{array}{l}\text { - Order Fulfillment Checklist } \\
\text { - Payment Receipt (In Full) }\end{array}$ \\
\hline
\end{tabular}

Based on table 6 above, the instruments applied in FAI have links to the processes that are happening within the FAI production process itself. The use of the instrument as a tool to help the communication process with the vendor as a reference in any communication process with the vendor or supplier to reduce the possibility of miscommunication between FAI and the vendor and vice versa. It can also be used as proof of recording for FAI itself, so that it has a clear track record compared to Function.id which does not have good records related to its production process.

In pre-production stage, vendor list and supplier list are used to help FAI to screening for its vendor and supplier based on its need, in order to have a vendor and supplier list DOI: http://dx.doi.org/10.24018/ejbmr.2020.5.4.446
FAI have to do a survey for vendor and supplier that fulfill their standards on vendor or supplier qualification, also with the designer that provide the product design for vendor. Request for quotation is used by FAI to confirm to its vendor and supplier whether the vendor and supplier could fulfill FAI request of an order, and could offer its best price. Then continue with purchase order as a proof that both parties agree with the price and specification that has been ordered, payment receipt is used as a proof of payment that have been made. Lastly in pre-production stage is good received checklist that is used for FAI supplier, to check whether the delivered raw material is match with the specification from FAI.

In production stage, order fulfillment checklist is used by FAI to reassured the order made by FAI to each vendor used, and to make sure that the material ready and also used to check the final product received by FAI when the vendor deliver it. During the process of production, FAI also have a quality control checklist to make sure that the product being produced by the vendor is in accordance with the quality standards of FAI. Continue with goods received checklist like in the pre-production stage that is used to check whether the finished product is in accordance with the order. Then in FAI itself, there are assembly checklist as a guidance during assembly process and inventory receipt to record finished product and the remaining material from production.

\section{CONCLUSION}

As mentioned in the earlier chapter that property business has a good potential in Indonesia, the rise and fall of the property industry goes hand in hand to the creative industry in the furnishing sector which also has good potential as well as be shown by the appetite of foreign furnishing companies in Indonesia. Various types and models of furnishings began to drive the Indonesian furnishing market, from what used to have a vintage theme with solid wood, now it has begun to shift towards minimalist furnishing models. This shift is supported by minimalist houses concept and apartments that began to bloom. Thus, the furnishing business began to establish to fulfill the need for a product with minimalist types and space saving like Function.id.

With a production process that relies on vendors (outsourced) without a structured process, Function.id cannot last long because several vital problems. Function.id then decided to make a change in management and brand to become Function ART Indonesia, with a new vision and mission and production process developed from Function.id. In the process of analyzing Function.id, researcher found several root causes, those problems were no designer specialist, limited source of vendor, lack of supplier source, having no a precise and measurable product design for vendor, having no clear letter of agreement, unstructured communication process, unstable ordering pattern, and having no standardization guidelines.

Some of the issues in Function.id can be solved with fairly simple solutions including surveying vendors and suppliers, collaborating with designers and making letters of agreements. Because these problems are not directly related to vendors who have an important role in Function.id and FAI later. So, the focus of this research is solving the issue 
of unstructured communication processes, unstable ordering patterns, and having no standardization guideline. By standardizing the production process for FAI in the form of flowcharts as explained in figures 3 and 4, making instruments for the communication process as in table 6 , and applying Heijunka method for ordering patterns so as not to burden the vendor. And how to implement the production process strategy for Function ART Indonesia by combining the production process with the instrument, accompanied by determining the ideal processing time as guidelines in the production process of FAI to avoid any undisciplined time in the process in order to not cause other problems in the production process that will be implemented in FAI.

\section{REFERENCES}

[1] Tahun depan sektor properti berpotensi makin cerah. Published: Sept 23.2019 .2 https://www.rumah.com/beritaproperti/2019/9/183287/tahun-depan-sektor-properti-berpotensimakin-cerah

[2] Maxwell, J.A., 2005, Qualitative research design: An interactive approach ( $2^{\text {nd }}$ ed), Thousand Oaks, California: Sage Publications.

[3] Keyton, J., 2011, Communication and organizational culture: A key to understanding work experience, Thousand Oaks, CA: Sage Publications.

[4] Guffey, M.E. \& Loewy, D., 2010, Essentials of Business Communication. Boston, United States of America: Cengage Learning.

[5] Montgomery, C Douglas. (2009). Introduction to Statistical Quality Control. United States of America: John Wiley \& Sons.

[6] Brousseau, E. \& Glachant, J.M., 2002, The Economics of ContractsTheories and Application. The Press Syndicate of The University of Cambridge.

[7] Bhattacharya, J., 2015, Guidance for preparing standard operating procedures (Sops). IOSR Journal of Pharmacy, 29-36.

[8] Moekijat. 2008, Administrasi Perkantoran, Bandung, Indonesia: Mandar Maju.

[9] Lunenburg, F.C., 2010, Communication: The process, barriers, and improving effectiveness. Schooling, 1.

[10] Kapur, R., 2018 Barriers to effective communication. Published: March

2018. https://www.researchgate.net/publication/323794732_Barriers_to_E ffective_Communication.

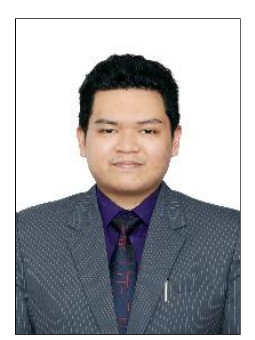

Demara Bijak Kurniawan was born on September 12, 1995 in Jayapura, Indonesia. He graduated from Telkom University in 2015 majoring in management business of telecommunication and information. $\mathrm{He}$ continued his post-graduate in Masters of Business Administration at Bandung Institute of Technology, Indonesia, and graduated in 2020. Demara B.K is currently an entrepreneur in the Building Furnishing Industry.

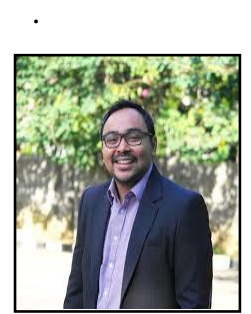

Sonny Rustiadi was born on November 21, 1982 in Indonesia. He completed his doctoral program at Goldsmiths, University of London, England in 2015. Sonny Rustiadi, S.E., M.B.A., Ph.D. currently worked as a lecturer of entrepreneurship and Director for student affairs at School of Business and Management, Bandung Institute of Technology. 